curiosily cannot he frequent among men who know too much of pail, and are too eager to alleviate it willıngly to inflict it. I am convinced that Sir Thomas Watson, profoundly humane as he $w d s$, would not haved s-euted from this opiniou I have been so b.l.t as to expres*. But wh+n I use h's own word 'humane,' I mean that he was ben'gnaut. He had a gracioune-s, a symuathy, a quicknes 10 uuders and, a liberal openness of mind, and a gentle, as iuring courtisy, which gave courage to those who came to contids in him, and at least did somewhat to alleviate the alarms which add fresh hurdens to those of disease. He could not be ill. mannered; he could nut torgt what was due to others; ab ive all, he was a deeply relig'ous man. "It is a cmmm spe ch,' says an old writer, 'ubi tres medici dun athri.' Turese doctors, two douht-rs. But it is not hard to explia why doctors are regarded by perp'e who do not think ar indiffer ent or opposed to religiou. Very oft-n thev have had tu set themselves in oppo.ition to teachings and practic $s$ which were connecterl with religion, and thus they were held $t$, be attacking relirion irself. The very momeut medicine b gan to distinguish itself from majic, that monent it must huve excited the enmitv of the prufessors and practisers of $m+g, c$ who were generally prie-t;. 'Docto's,'says Mr, Mathew Arnold, 'are the nutural friends of lu.idity,' and hr d-tine. lucidity as 'the perception of the want of truih aud valit ness in nutions long current, the perception that they are no longer $p$ ssible, that ther time is tini-hed, and thry cin serve us vo more.' Rational medicine became pussinle when at length charms and incantainus were seen to he worthless, and ratioual mudicine must at first have been looked upon as a rebelion aginst reliuion. Then, ayan, the study of physical science, which includes that of the? human organism, was looked upon for geverations wi h suspicion, and Chri-tian ecclesias'ics, and even a Pope, fell under suspicion of heresy, because of his scient fi ; investigations. The same dark shadow could rest upon the doctors and would do much to deter earnest Churchuen from adoptiog the medical profession. It fell, therefore, intio tie hands of Jews aud Arabs, anong whon lived on the tra. ditions of Greek schools and freer days; and it has been said that ' in the eleventh century nearly all the physicians in Europe were Jews' (Draper). But Arabs an I Jews, to the Cnurch, were iufidels - in other words, doctors were infidels; and men have gone on saying this, or sometbing like it, until the present day. But, speaking from a fairly large experience, I should say the contrary. Iusteal of les., I have :een more reverence and piety of siul among docturs than among other classes of men. And I should naturally expect it. 'These meu see the wonders of the Lord.' Fuppery and frivolity may have no feeling, and fools miy say there is no God; bat intel ecturl eminence gives a man a vision denied to the vacaut and the idle. Sir Thomas Watson was a truly and unaffe tedly religions man. For many years, how many [ know nist, each Siund ty saw hım in this church, and to the last his venerable devoti in was expressed at the Lord's table. Various wrre the siles of truth which were presented to him in the minstry of this clsurch, but $I$ am sure that to alt he gave the con-ideration of a temperate and unprejudiced judyment. That which he cruld take be took, anil at least his prayers always overshanowed him with henediction. 'I have no genius for disputes in seligion,' he might have sid, with Sir Thumas Browue. "He was a man of peace, and the blessing of the peace-maker is his." 'The profession of medicine,' he sald, 'having for its end the good of mankind, knows nothing of national eumities, of political strife, of sectarian division.?' I cannot more fit'y close this sermon than in words of his own which were suoken on the death of his filend Dr. Peter Mere Latham, and which I will say of himst lf, "Ripe in years and rearly in spirit for the solemn change, his death must long be the subject of tender and sacred regret among the nearest and dearest of his surviving friends; nor will his memory soon cease to he reverently cherished thronghout a much wider circle.' Not as ' water spilt upon the gronnd,' is the life we seem to have lost. His are the two immortalities which are granted to the good. And sptcially let me say to you members of the nuedical profession, to so many of whom it is my great privilege and responsibility to miuister, that life of nobleness is still with you, and will be with those who shall come after you, even when no consuions memory of it remains; and that you, too, may reach that high life over which death ha'h no dominion, is the "earuest desire and prayer of your friend aud pastor."

\section{DR. MOXON'S LECTURE ON "FEVER."}

\section{To the Editor of THE LANCET.}

Sir, - Will you grant me space while I venture to make what appears to me a needful remark on a pint iu Dr. Mixon's attractive lecture on "Fever," which we have all read in your issue of Dec. 2 nd.

I allude to his criticism, severe in $f(r m$, thowgh in manner gentle, delivered on a defiaition of "fever" oc surring in a book which the lecturer and most of us reyard as "the best recent work on medicine." And here I woald ask Dr. Moxon's pardon if I wrongly take his remarks so mush an sérieux, as his many readers have doubleas dine, from the prominense both of the lecturer and the lectare. I would plead, as my reason for writing, the simple derire of at. te inpting to counteract the very false impression lik+ly to be produced by this somewhat plausible attak on a very solid work.

In a passage reminding one a little of a "losic paper" in an examination, Dr. Moxon treats wit' sume deri-ion a definition of fever which he aupears to quote from the work allıded to, as $\mathrm{f}$ llows: "By the term tever is meant that abstract conditinn which is common to all st-called fehrile dis orders, and the presence of which sives them clarm to that designation"; aud he p.oc eils to accuse the witer of the coufe-sed'y unpardonats sin of in cluling in the terms of h's definit on the rery thing to $b$, definel. But an accurate quota ion of the o iginal deprives that seemingly formidable crivicism of at its terrur. Dr. Moxon's edition of it is gurbell and im. puffect; garbled unintentionally, no dou's, in that certain luverted commas (in this instance of 10 sic.l iupurtince) are ignored; imperfect, in that an exsential part of the definiion is altogether omitter. Here is the original author's own stateruent: "By the tern faver is mext that abstract condition which is cowmon to all so.ralled 'febrile disorders,' and the presence of wheh gives them their claim

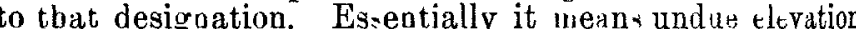
of temperature, the immediate or proximtie cause of that elevation, and the consequeuces which these conditions entall." A moderately coreful reading of this will show that Dr. Moxon has resorted to the tine bonoured and classical device of setting up an imasiarry adversary in order to have the pleasure if knocking something down. The term "so-called febrile disorders" is obvi msl, used in this well-known book on medicine as a coideused formula to exuress convt nienily the series of distants-typhus, ty $\mu$ hoid, variola, searlatina, \&c. ; this being cle tuly wown by toe words "so-caller" and the iaverted . ommas, which mark the term "febrile disorders," both of which are innored by Dr. Muxon. Had the author of the bwk in quesion given his list of disea-es explicitly, in-tead of hav ng recourse to a grouving mark or furmula, the airy shaft of his ciitic could never have bren shot at all, for it would have luked even the formal plausibility that it now posse-ses. The definition in the book as it, stands is cerrainly clear, and, as far as 1 can see, gıilles of any logi'al flaw.

For his weli-timed aud briliant attack on the frequent and uusavoury medical bulletic, which gives a bad taste to the reader, as a necessary consequen e of that evliced by its -ignatorles, Dr. Moxon has the corilial thants of the profession at large. Such a serious warıing, howerer, would have sounded t.rther and more soletwuly h.d it, nut been set in the midst of the digressive logomachy of this extraordinary and very interesting lecture.

I am, Sir, yours faitlıfully, H. DONKIN.

Upper Berkeley-street, Portman-square, Dec. 13th, 1882

Provident Surgical Appliance Society.-On the 14th in-t. the decennial festival of this sucjety was held in the Cannon-street Hotel. The chairman, in rroposing the toast of the evening, stated that, whilet tormerly it was the practice to exrend aid to tho:e only who succerded in ubtaining the requisite number of suhaciibers' lickets, nor apolicants were ielieved from this irksome and difficult requirement. During the ten years of the Society's esi.tence 25,000 surgical apulidnces had been distifut $d$. In the course of the evening the receipt of $£ \notin 50$ in subseriptions was announced, 